\title{
Influence of the philosophy of language to writing of Slovak poetess Mila Haugova
}

\author{
[Vplyv filozofie jazyka na tvorbu slovenskej poetky Mily Haugovej]
}

\author{
Eva Hohn
}

DOI: $10.18355 /$ XL.2018.11.02.57

\begin{abstract}
Poetess Mila Haugová has been known to Slovak audience for more than three decades. Her literary activity began in line with the Slovak symbolism. In the nineties of the 20th century the poetry of Haugová's poems changed. This process began after a short break, when Mila Haugová was engaged in translation activities, mainly from the contemporary Austrian literature. In our text, we have attempted to show, that this change occurred under the influence of the philosophy of language, which Haugová took from the Austrian author Ingeborg Bachmann as well as from the philosophy of poststructuralism. In the first part of the article we explain the concept of Bachmann's language critique, which was elaborated under the influence of the Austrian philosopher Ludwig Wittgenstein, especially his work Tractatus Logico-Philosophicus (1921). The second part of our article focuses on the influence of psychoanalysis and poststructuralism on Mila Haugová's poetry. Through the language, the Slovak poetess creates a new, own world of poetry. Crossing the borders of the language also represents crossing the borders of the being. This process is closely linked to the identity of the poet, whose existence acquires through writing a new, higher quality.
\end{abstract}

Key words: philosophy of language, existentialism, poststrukturalism, psychoanalysis, Slovak literature, Austrian literature

\begin{abstract}
Anotácia
Poetka Mila Haugová je slovenskému publiku známa už viac než tri desat'ročia. Svoju literárnu činnost' začala v súlade so slovenským symbolizmom kraskovskej línie. V devät'desiatych rokoch 20. storočia sa poetika Haugovej básní mení. Tento proces sa začal po krátkej prestávke, počas ktorej sa Mila Haugová venovala prekladovej činnosti, hlavne zo súčasnej rakúskej literatúry. V našom texte sme sa pokúsili ukázat', že táto zmena nastala pod vplyvom filozofie jazyka, ktorú Haugová recipovala na základe lektúry rakúskej spisovatel'ky Ingeborg Bachmannovej ako aj filozofie postštrukturalizmu. V prvej časti článku objasňujeme koncept Bachmannovej jazykovej kritiky, ktorý si vypracovala pod vplyvom rakúskeho filozofa Ludwiga Wittgensteina, najmä jeho diela Tractatus Logico-Philosophicus (1921). Druhá čast' nášho článku sa venuje vplyvu psychoanalýzy a postštrukturalizmu na poéziu Mily Haugovej. Prostredníctvom jazyka vytvára slovenská autorka nový, vlastný svet poézie. Prekračovanie hraníc jazyka predstavuje zároveň prekročenie hranice bytia. Tento proces je úzko spojený s identitou básnika, ktorého existencia nadobúda prostredníctvom písania novú, vyššiu kvalitu.
\end{abstract}

Kl’účové slová: filozofia jazyka, existencializmus, postštrukturalizmus, psychoanalýza, slovenská literatúra, rakúska literatúra

\section{Úvod}

„Myslím, že básnik má právo na všetko. Aj zmenit' poetiku. Možno je u mňa vývoj opačný, na začiatku tvorby som seba aj svet vnímala celistvejšie, ale potom sa pre mňa svet roztrieštil; stratami, hladaniami, aj slepými uličkami a moja výpoved' začala byt' fragmentárnejšia [...]. Nikdy som sa, myslím, nepúštala l'ahšou cestou komunikatívnosti... čitatel'a nešetrím a ani na neho pri písani nemyslím " (Haugová, 2013: 45). 
Vyjadrenie Mily Haugovej napovedá najlepšie, čo by sme v našom článku radi priblížili. Na začiatku stojí predpoklad, že lektúra a preklady tejto známej slovenskej poetky, ktorým sa venovala v druhej polovici 80 . rokov minulého storočia, ovplyvnili jej vlastné texty a podl'a nášho názoru možno hovorit' o zmene poetiky jej tvorby v na to nadväzujúcom období, teda v 90 . rokoch minulého storočia. ${ }^{1}$

Ked' ešte pod pseudonymom Mila Srnková vydala v roku 1980 svoju prvú básnickú zbierku Hrdzavá hlina, bola jej poézia charakteristická viazaným veršom, rytmickou štruktúrou a d’alšími tradičnými lyrickými výrazovými prostriedkami. ${ }^{2}$ Odklon od týchto príznakov možno pozorovat' v básnickej zbierke Premenlivý povrch $(1983)^{3}$. V básnických zbierkach vydaných v nasledujúcej etape 90 . rokov je už na prvý pohl'ad výrazná zmena. $\mathrm{V}$ tejto fáze tvorby sa poetka odkláňa od svojich typických výrazových prostriedkov a básnické zbierky Čisté dni (1990), Praláska (1991), Nostalgia (1993), Dáma s jednorožcom (1995), Alfa Centauri (1997), Krídlatá žena (1999) a d’alšie nadobúdajú charakter vel'mi subjektívnej, autenticky ladenej poézie. Typickými znakmi tejto lyriky sú vol’ný verš, asociácie, spomienky, monológy, komentáre, citáty a montáže. K tomu sa pridružuje častá zmena lyrického subjektu, tematizácia mýtov, rozprávok a pod. Dominantnými témami daného obdobia sa stávajú otázky spojené s bytím a jazyková hra.

Uvedený proces nastáva po šest'ročnej publikačnej prestávke v druhej polovici 80 . rokov, počas ktorej sa spisovatel'ka, ako sme už spomenuli, vo vel'kej miere venovala lektúre a prekladom zo svetovej literatúry. ${ }^{4}$ Zmena poetiky v tvorbe Mily Haugovej sa podl'a nášho názoru odohrala recepciou kritiky jazyka rezonujúcej v umení a vo filozofii v druhej polovici 20. storočia. Zasiahlo to aj literatúru rakúskej proveniencie, ktorej sa slovenská poetka v danom období intenzívne venovala (Hut'ková, 2017: 101). Uved'me napríklad jej preklady Friederike Mayröckerovej, Paula Celana, Georga Trakla či Ingeborg Bachmnannovej. Pri poslednom mene sa v tejto súvislosti pristavme o niečo dlhšie.

\section{Vplyv koncepcie jazyka rakúskej spisovatel'ky Ingborg Bachmannovej}

Sympatie so súčasnou rakúskou spisovatel'kou Ingeborg Bachmannovou nemožno v tvorbe Mily Haugovej z 90. rokov minulého storočia prehliadnut' a lektúra a preklady z jej tvorby zanechali na textoch slovenskej poetky výrazný vplyv. ${ }^{5}$

\footnotetext{
${ }^{1} \mathrm{Na}$ domácej literárnej scéne pôsobí už od začiatku 80. rokov a o dimenziách jej tvorby svedčia viac než dve desiatky básnických zbierok, dve knihy memoárov, ako aj preklady predovšetkým básnických textov z nemeckej, mad’arskej, anglickej, japonskej a i. literatúry. Poetkine básne sa dočkali viacerých prekladov (do angličtiny, nemčiny, francúzštiny, ruštiny, gruzínčiny a pod.), ako aj literárnych ocenení. Z nich uved’me aspoň Prémiu literárneho fondu za pôvodnú literárnu tvorbu, Cenu Klubu nezávislých spisovatel'ov či Cenu Dominika Tatarku. V roku 2002 vychádza od Stanislavy Chrobákovej-Repar rozsiahla knižná štúdia poézie Mily Haugovej pod názvom Mila Haugová.

${ }^{2}$ O poetike tejto fázy tvorby hovorí Stanislava Chrobáková-Repar ako o „konfrontáci[i] s umiernenou symbolistickou poetikou kraskovského či hal'amovského typu“ (ChrobákováRepar, 2002: 13 - 14).

${ }^{3}$ Viac pozri: Chrobáková-Repar (2002: 31).

${ }^{4}$ Viac pozri: Chrobáková-Repar, 2002, kapitola Druhé intermezzo: Labyrint mlčania.

5 Ingeborg Bachmnnová sa narodila v roku 1927, vyštudovala filozofiu na univerzite vo Viedni, kde u filozofa Viktora Krafta, člena Viedenského krúžku, obhájila dizertačnú prácu Kritické prijatie existenciálnej filozofie Martina Heideggera (Die kritische Aufnahme der Existentialphilosophie Martin Heideggers, 1950). Po druhej svetovej vojne bola v Nemecku považovaná za jeden z najvýraznejších talentov povojnovej literatúry nemecky hovoriacich
}

XLinguae, Volume 11, Issue 2, April 2018, ISSN 1337-8384, eISSN 2453-711X 
Báseň Nebudeme chýbat? (Praláska), venovaná Ingeborg Bachmannovej, je variáciou známej básne Povedz mi, láska od tejto rakúskej spisovatel'ky.

Chýbame, láska.

Musíme mysliet'.

Nevynecháme nehu,

platíme za ňu kožou,

ženie nás zradná krv. [...]

Na striebre piesku krepči plachý škorpión ... (Haugová, 1991: 27).

Na striebre piesku krepčí plachý škorpión [...].

Povedz mi, láska, to, čo neviem sama:

v tom krátkom strašnom čase mám sa stýkat'

len a len s myšlienkami, nepoznat'

nehu a nehu vôbec neprežit?

Musíme mysliet? Nebudeme chýbat?

(Bachmannová 1986: 514).

V rokoch 1993 a 1995 preložila Mila Haugová štyri Bachmannovej básne: Monológ kniežat’a Myškina..., Vy slová, Chod', myšlienka, Žiadne lahôdky, ako aj dve eseje - Pravda je l'ud'om prístupná a Literatúra ako utópia. V roku 2003 vychádza Haugovej preklad Bachmannovej básní z pozostalosti pod názvom Nepoznám iný lepši svet. V roku 1995 publikovaný text Telo slova je môj čas od Mily Haugovej je zas holdom na Bachmannovú a v rovnomennej Haugovej básni (Telo slova je môj čas) z básnickej zbierky Alfa Centauri nachádzame centrálnu postavu Rusalky z Bachmannovej poviedky Undine.

V tom istom období vychádzajú v básnických zbierkach Čisté dni a Praláska dve básne slovenskej poetky: Goya (Čisté dni) a Svedomie (Praláska). Druhá báseň je uvedená citátom Charlesa Baudelaira: „A temné zrenice upreté do prázdna ...", nastol'ujúcim problém, ktorým sa Ingeborg Bachmannová zaoberala ako ešte len dvadsat’štyriročná študentka filozofie vo svojej dizertačnej práci. ${ }^{6}$ Mená práve týchto dvoch velikánov umenia, Goyu a Baudelaira, uvádza totiž ku koncu svojej práce, ked' uvažuje nad možnost'ami umenia reprezentovat' tie sféry života, ktoré nie sú uchopitel'né filozofiou. V súvislosti s tým sa v práci dočítame: „Potreba vyjadrenia tejto inej [emocionálnej] sféry skutočnosti, ktorá sa vymyká fixácii systematizujúcou existenciálnou filozofiou, prichádza v ústrety umenie so svojimi mnohorakými možnost’ami v omnoho vyššej miere“ (Bachmann, 1985: 116, prel. E. H.). Vzápätí spisovatel'ka uvádza obraz Kronos pohlcuje svoje deti od Francisca Goyu a báseň Priepast' od Charlesa Baudelaira ako príklady zobrazenia konfrontácie moderného človeka so strachom a ničotou:

Tmy spánku desím sa jak iní temných jám, tých hmlistých trasovísk, čo vedú neviem kam.

Bez konca vidím zem na všetky, všetky strany ... [...]

(Baudelaire, 1995: 61).

krajín. Od konca 50. rokov minulého storočia až do svojej smrti (1973) žila v Ríme. Od roku 1977 sa v jej rodnom meste Klagenfurte každoročne udel’uje mladým talentom literárna cena Ingeborg Bachmannovej. Okrem poézie je autorkou rozhlasových hier, libriet, esejí a prózy.

${ }^{6}$ Svoju prácu písala v prospech logického pozitivizmu a jeho kritiky existenciálnej filozofie Martina Heideggera. Od poznávacej metódy logického pozitivizmu sa neskôr dištancovala vo svojich esejách o Viedenskom krúžku a Ludwigovi Wittgensteinovi (Pecníková, 2016: 1240). 
Baudelairom často tematizovaný zápas moderného človeka o zmysel života rezonuje $\mathrm{v}$ kontexte nanovo nastolených existenciálnych tém aj v poézii Mily Haugovej z fázy 90 . rokov minulého storočia, v ktorej verše tematicky príbuzné baudelairovskej poézii znejú:

Slepí tancujú v noci.

Hladkajú si pomätenú tvár.

Uhádnu hádanku, ktorú

im dala smrt'

[...] (Goya, Haugová, 1990: 38).

Vezmi ma so sebou do pekla, ktoré si privlastňuješ, do horúcich

nedýchatel'ných nocí [...] (Svedomie, Haugová, 1991: 61).

Z d'alších veršov uvedených básní je možné usúdit', že práve prostredníctvom umenia nadobúda existencia človeka pre obe spisovatel'ky novú, eticko-existenciálne motivovanú kvalitu. ${ }^{7}$ Tvorba sa stáva záchranou, „miestom“ úniku pred prázdnotou, pred stratou zmyslu sveta. Práve vd’aka nej nadobúda život svoj ciel'. Pripomeňme si, že to bol už Aristoteles, ktorý považoval tvorbu (téchne) za najvyšší ciel' bytia. Tvorba bola preňho zároveň predpokladom na nastolenie prirodzeného poriadku (telos), na stvorení sveta. Teda aj umelecká činnost' spĺn̆a dôležitú poznávaciu funkciu, ${ }^{8}$ čo znamená, že cez ňu nadobúda existencia novú dimenziu. Na objasnenie tejto témy rezonujúcej v tvorbe Mily Haugovej v 90. rokoch minulého storočia majú obzvlášt' vel'ký význam filozofické úvahy Ingeborg Bachmannovej (Mistrík, 2016: 107) ${ }^{9}$.

Vyššiu, etickú kvalitu života prostredníctvom literatúry (tvorby) vytýčila Ingeborg Bachmannová na základe svojho záujmu o filozofiu jazyka, a to tým, že vymedzila hranice medzi každodenným a literárnym jazykom. Učinila tak po svojej lektúre rakúskeho filozofa Ludwiga Wittgensteina a jeho diela Tractatus logico-philosophicus (1921). Ak uvážime, že v básňach slovenskej spisovatel'ky možno takisto nájst' citáty od Ludwiga Wittgensteina, môžeme sa priklonit' k nami nastolenému predpokladu, akým je vplyv filozofie jazyka na Haugovej tvorbu 90. rokov. ${ }^{10}$ Odkazuje na to aj d’alší moment - vo všetkých Bachmannovej textoch, ktoré začiatkom 90. rokov preložila Mila Haugová, je problematika jazyka ich ústredným motívom.

Ludwig Wittgenstein sa v Traktáte pokúsil ukázat', že zmysluplné výpovede možno učinit' len na základe empiricky verifikovatel'ných skutočností: „O čom nemožno hovorit', o tom treba mlčat"“ (Tractatus, ${ }^{11}$ veta 7 ). A ked’že v jazyku sú podl'a neho zmysluplné len empiricky verifikovatel'né skutočnosti, je nemožné hovorit' o niečom, čo nezodpovedá nároku logiky. Otázky etiky, estetiky a náboženstva zostávajú podl’a Wittgensteina za hranicami vyslovitel'ného: „Preto nemôžu existovat' ani vety etiky. Vety nemôžu vyjadrovat' nič vyššie“ (T 6.42). „Je jasné, že etika sa nedá vyslovit’. Etika je transcendentálna. (Etika a estetika sú jedno.)“(T 6.421). Hlavným Wittgensteinovým zámerom bolo síce vymedzenie hranice

${ }^{7}$ U Mily Haugovej je to potrebné vnímat' aj v kontexte straty druha a priatel'a, maliara Petra Ondreičku (1947 - 1990). Aj preňho bol Francisco Goya vel'kým umeleckým vzorom.

${ }^{8}$ Viac pozri: Pochat (1986: 48).

${ }^{9}$ Pre hlbší prienik do otázok umenia a identity hovorí Erich Mistrík v knihe Estetická výchova ako nástroj sebareflexie. Autor tu poukazuje na to, že umelecká recepcia má existenciálny význam, v živote človeka je udalost'ou a pomáha formovat' jeho identitu.

${ }^{10}$ Napríklad v básni Blizkost' k bytiu (Nostalgia) nachádzame úvodný citát z knihy $O$ istote od L. Wittgensteina: „Ak vieš, že je tu ruka, tak všetko ostatné ti uznáme“ (Wittgenstein, 2006: 1).

${ }^{11}$ Ďalej už len $\mathrm{T}$.

XLinguae, Volume 11, Issue 2, April 2018, ISSN 1337-8384, eISSN 2453-711X 
medzi vyslovitel'ným a nevyslovitel'ným, no paradoxným zostáva fakt, že hoci nevyslovitel'né (etiku, estetiku) vymedzuje ako sféru nezmyselného, zároveň ho akceptuje. ${ }^{12}$

Bachmannová sa ako spisovatel'ka bránila proti logicko-empirickému určeniu jazyka, a preto sa nezamerala len na Wittgensteinovu logickú analýzu. Do centra jej pozornosti sa dostáva predovšetkým Wittgensteinovo „zoufalé úsilí o nevyslovitelné, [...] tedy ztroskotání jeho snahy o pozitivní vymezení filosofie [...]“ (Bachmannová, 2010a: 8). Podl'a Bachmannovej Wittgenstein ukázal hranicu nielen jazyka, ale aj sveta, ked' skonštatoval: „Logika vypĺňa svet; hranice sveta sú aj jej hranicami“ (T 5.61). Filozof tak urobil podl’a autorky preto, lebo ako sám povedal: ,,[subjekt] je hranicou sveta“ (T 5. 632). ${ }^{13}$

Myšlienky z Traktátu, hlavne jeho druhej časti, sú podl’a Bachmannovej prekročením metódy logickej analýzy, pretože pravda, ktorú ponúka logika, je neuspokojivá. Wittgensteinom vytýčenú hranicu autorka načrtáva takto: „A co je tedy toto nevyslovitelné? Nejprve se s ním setkáváme jako s nemožností zobrazit samotnou logickou formu. Ta se ukazuje. Zrcadlí se ve větě. Věta jí vykazuje“ (Bachmannová, 2010a: 14). Ked’že je podla Bachmannovej logická forma nezobrazitel'ná, stojí na hranici vyslovitel'ného, ,a ježto logika vyplňuje svět, ježto svět vstupuje do struktury logické formy, jsou její hranice hranicemi našeho světa. Takto chápeme vetu: ,Hranice mého jazyka znamenají hranice mého světa‘ (T 5.6)“ (Bachmannová, 2010a: 14). Svoju pozornost’ autorka upriamuje na poznávací subjekt a na hranicu, ktorú Wittgenstein vymedzil už spomenutou vetou: „Subjekt nepatrí k svetu, ale je hranicou sveta." Prechod od zlého (Gaunersprache) k novému jazyku je sprevádzaný existenciálnou skúsenost'ou, a s tým spojenou novou morálkou, pretože, ako hovorí autorka, všetky predpoklady jazyka spočívajú v morálke (Dolník, 2013: 94-97). Vo svojej prvej frankfurtskej prednáške Otázky a pseudootázky o tom píše: „S novou řečí čelíme skutečnosti vždycky tam, kde dochází k morálnímu, poznávacímu zvratu, a ne tam, kde se někdo pokouší vytvořit řeč samu o sobě novou, jakoby se řeč sama mohla domoci poznání a sdělit zkušenost, kterou pisatel nikdy neučinil“" (Bachmannová, 2010b: 73). Ludia stratili poznanie veličín dobra, lásky a viery. Slovami filozofa Martina Heideggera „homo barbarus musí hl'adat' spät' homo humanus“, a ak sa má „,[...] člověk ještě jednou dostat do blízkosti bytí, musí se nejprve naučit existovat $\mathrm{V}$ bezejmennosti“" (Heidegger, 2000: 12). ${ }^{14}$ Z vyjadrení Ingeborg

12 Viac pozri: Zimmermann (1975: 62). Pre svoju argumentáciu Wittgenstein rozdelil výpovede na zmysluplné, zmysluprázdne a nezmyselné. Zmysluprázdne sú vety logiky.

${ }^{13} \mathrm{~V}$ období pred vznikom Traktátu Wittgenstein spolupracoval s kruhom umelcov, filozofov a publicistov združených okolo časopisu Der Brenner. Ich obl’úbeným filozofom bol Søren Kierkegaard a v časopise publikovali napríklad G. Trakl, K. Kraus a i. „Nemožno spochybňovat', že Wittgensteinovo zdôrazňovanie ,etického významu', na ktorý sa Traktát vzt'ahuje, je ovplyvnené brennerským kruhom a podnietené lektúrou Kierkegaarda. Nasvedčuje tomu aj okolnost', že svoje pojednanie ponúkol Wittgenstein na uverejnenie práve prostredníctvom Ludwiga von Fickera - s poznámkou, že ide práve tak o literárne ako o filozofické dielo a že preto je na správnom mieste vo vydavatel'stve, ktoré publikovalo Haeckerove diela“" (Zimmermann, 1975: 44).

„Es kann kaum bezweifekt werden, daß Wittgensteins Betonung des „ethischen Sinnes“, dem der Tractatus verplichtet sei, vom Selbstverständnis des Brenner-Kreises geprägt und durch die Lektüre Kierkegaards nahegelegt worden ist. Dafür spricht auch der Umstand, daß Wittgensetin seine Abhandlung gerade durch Ludwig von Ficker zur Veröffentlichung angeboten hat - mit der Bemerkung, daß es sich ebensosehr em ein literarisches wie um ein philosophisches Werk handele und daß es daher in einem Verlag, der die Werke Haeckers publizierte, am richtigen Platze sei“ (Zimmermann, 1975: 44).

${ }^{14}$ Nádej na zmierenie konfliktov súčasnosti vyjadruje Ingeborg Bachmannová slovami: „A já nevěŕm $\mathrm{v}$ tento materialismus, $\mathrm{v}$ tuto konzumní společnost, $\mathrm{v}$ tento kapitalismus, $\mathrm{v}$ tuto nehoráznost, která se tu děje, obohacování lidí, kteří nemají právo se na nás obohacovat. 
Bachmannovej aj nemeckého filozofa existencializmu Martina Heideggera zaznieva konštatovanie obrovskej kultúrnej krízy, ktorej dôvody spočívajú v strate duchovnej a morálnej orientácie dneška (Pecníková-Slatinská, 2017: 320).

Nárok na novú morálku a nový jazyk kladie rakúska autorka hlavne na spisovatel'a, pretože on je pre ňu nositel'om poznania a spolu s ním aj nového jazyka. ${ }^{15} \mathrm{~V}$ eseji Pravda je l'ud'om prístupná, ktorý do slovenčiny preložila Mila Haugová, sa dočítame: „Teda úlohou spisovatel'a nemôže byt' popieranie bolesti, zastieranie jej stôp, či zámena za niečo iné. Musí si bolest' naopak uvedomit' a aby sme ju mohli uvidiet', musí ju ešte raz odhalit' [...]“ (Bachmannová, 1995: 6). Spisovatel’ má v rukách nástroj, literatúru, akým možno ukázat' zlo sveta a pokúsit' sa o jeho nápravu.

Existenciálny rozmer hranice jazyka a sveta ovplyvnil podl’a nášho názoru Milu Haugovú rozhodujúcim spôsobom. Počnúc básnickou zbierkou Čisté dni sa pre n̆u jazyk literatúra stávajú „domom bytia“, miestom, bez ktorého niet inej možnosti existencie. Aj z tohto dôvodu sú nový jazyk, hranica jazyka a sveta hlavnými motívmi tvorby 90. rokov. Uved'me len niekol'ko z mnohých príkladov hranice jazyka a jazyka ako heideggerovského „domu bytia“" z veršov Mily Haugovej

Niekedy nemôžem hovorit' o ničom, [...]

verš sa dvojjazyčne zadŕha v hrdle. [...]

Len uvol'nit' zovretie žeravých viečok,

len dovolit' rukám dotýkat' sa,

len otvorit' ústa čistému slovu, [...]

(Čisté dni, Haugová, 1990: 64, 65)

... unvollendete... slová miznúce v cudzom jazyku,

Slová, ktoré prepisuje jazyk osamotene sa chvejúci...

...Teraz pre túto chvíl'u neexistuje hranica. Zjaví sa, ak

sa ju pokúsim prekročit? (Nostalgia, Haugová, 1993: 104).

Nie to čo jestvuje prítomnost'ou. Subjekt chce niečo iné:

(...) na tom istom mieste iné sny, láskavý lukostrelec

so šípom, v ktorom sa udržal vietor, ešte váha

... narodená

pre iné miesto ... (Alfa Centauri, Haugová, 1997: 9).

\section{Recepcia postštrukturalizmu}

Takto by sme mohli pokračovat’ naprieč všetkými básnickými zbierkami z 90. rokov. Nie je to však len hranica jazyka, ale predovšetkým hranica sveta, ktorú človek tvorbou prekračuje (Jančovič, 2013: 19). Ved' podl'a Wittgensteina je subjekt hranicou sveta. A tak Haugovej zápas o prekračovanie hraníc neutícha, naopak, nadobúda novú dimenziu. Daný proces sa paralelne odohráva aj na poeticko-jazykovej úrovni, pričom slovenská poetka siaha po pojmovom inštrumentáriu psychoanalyticky motivovanej koncepcie jazyka. Jadrom básnickej zbierky Nostalgia sa stáva cyklus pätnástich básní pod názvom Genotext a v roku 2001 vychádza pod týmto názvom celá básnická zbierka. Oslobodenie sa od symbolických štruktúr a performatívneho jazyka je typickým znakom uvedenej lyriky. Je to práve pojem genotext, ktorý použila Julia Kristeva, predstavitel'ka francúzskeho postštrukturalizmu. Za genotext považuje všetko, čo súvisí

Věřím opravdu v něco, čemu říkám ,nadejde den'. [...] Kdybych v to už dál nemohla věřit, nemohla bych ani dál psát" (Bachmannová, 2009: 232).

${ }^{15}$ V Poetike pripísal Aristoteles umeleckému poznaniu väčšiu váhu než vedeckému poznaniu (Aristotelés, 1996: 75).

XLinguae, Volume 11, Issue 2, April 2018, ISSN 1337-8384, eISSN 2453-711X 
s procesom vzniku významu. Ten je podl’a nej v úzkej závislosti od semiotického, čím označuje procesy, pri ktorých sa energia presúva a blokuje, ako napríklad pudové dispozície. Určité množstvá energie prebiehajú subjektom tak, že sa počas utvárania vzniku významu v závislosti od rodinných a spoločenských tlakov blokujú alebo prelínajú. Genotext sa dá v jazyku rozpoznat, avšak v zmysle štrukturalistickej jazykovedy nie je v texte rozpoznatel'ný. Existujú znakové systémy, ako napríklad hudba, ktoré spočívajú práve na semiotickom.

V d’alších básnických zbierkach najmä z druhej polovice 90 . rokov minulého storočia básne slovenskej poetky úplne strácajú funkciu významových celkov a až alogicky komponované verše pripomínajú vel’akrát viac hudobné a vizuálne než jazykové výpovede. Prostredníctvom jazyka sa v Haugovej „genotextovej“ lyrike pred nami otvára svet semiotických procesov, procesov vzniku významu. Slová, morfémy a hlásky zastupujú samostatné sémantické celky, čo v praxi znamená rozbíjanie významových polí, delenie lexikálnych jednotiek na morfematické časti a pod. Príznačnou črtou je nerešpektovanie písania vel'kých písmen, nedodržiavanie interpunkcie a i. Okrem toho v mnohých básňach možno odhalit' psychoanalyticky motivovaný pôdorys, pričom sa poetický jazyk podiel'a na vytváraní vlastnej identity básnického subjektu: „Puberta, do ktorej si híbime neisté zázemie. Každé odovzdanie je konečné? Sme zlodejky nepravých vecí?““ (Nostalgia, 1993: 65). Často využívaný motív zrkadla má podl'a nášho názoru takisto psychoanalyticky motivovanú funkciu. V psychoanalytickej teórii postštrukturalizmu predstavuje zrkadlo sebaodcudzenú identitu. ${ }^{16}$ Subjekt sa spoznáva len ako produkt cudzieho očakávania a predstáv a svoju klamlivú celistvost' situuje len na fiktívnej úrovni - v zrkadle. Identifikácia s obrazom druhho znamená potom vždy zneuznanie vlastného ja:

...za-nechaj stopu. stopu prstov,

dlaní, seba, krvi;

stopa slova je slovo vy-

trhnuté z tvojich mlčaní.

... u-kry sa v zrkadle,

v pre-trvávajúcej rane,

slovo vytesané znútra;

zmítvychvstanie (Nostalgia, Haugová, 1993: 74 -75).

Tu už nevrháš ani tieň

\section{do zrkadla;}

pokúšaš sa udržat', čo ti ešte

zostalo

svetlo svetla

svetlo tela

telo svetla

telo tela

pozmenený tvar cudzej duše (Nostalgia, Haugová, 1993: 40).Azda aj preto je v básnických zbierkach nasledujúcich po Nostalgii typickým príznakom hl'adanie identity. Básnické ja sa mení, vytráca, zomiera, rodí sa a štylizuje do iných subjektov, ako napr. v básni Socha (Nostalgia):

...pod', Théta po tejto ceste,

bez vynechania zákrut,

ne-píš,

ne-hovor,

16 Viac pozri: Lacan, 1973: 61 - 70. 
ne-pohni sa,

rovnako si ohrozená slovom

i mlčaním?

...kam sa schováš? tráva je

nízka, piesok sa rozsýpa medzi

prstami (len hlina, hlina nás prijme)

(Nostalgia, Haugová, 1993: 74).

Už v spomínanej básni Telo slova je môj čas figuruje ako jeden z mnohých náhradných básnických subjektov postava Undine, hrdinka z Bachmannovej rovnomennej poviedky. Avšak na rozdiel od Undine rakúskej spisovatel'ky, ktorej život v láske sa nenaplnil, a preto odchádza spät' medzi prírodné živly, je Haugovej Undine individuálno-psychologickou reprezentáciou básnického jazyka. Cez jazyk vytvára svoj vlastný svet poézie predstavujúci nový, „čistý“ svet. Svet Haugovej hrdinky sa napíňa prostredníctvom písania - tvorby. Nájdením nového jazyka sa literatúra stáva konkrétnou utópiou: „Navždy sa zatvoríš do slov kde chceš prebývat': s telom / vybaveným zúfalstvom: Undine ženský duch vody: priezračný oheň: / horiace vlasy, ústa ruky“ (Alfa Centauri, 1997: 63). Zbierky druhej polovice 90. rokov minulého storočia (Alfa Centauri, Dáma s jednorožcom) možno preto nazvat’ aj básnickými realizáciami poetických svetov.

Hladanie novej, eticky motivovanej identity lyrického subjektu v tvorbe Mily Haugovej je podl'a nás návratom k podstate a budovaniu novej, autonómnej existencie (Bednarova, 2011: 19). Na úrovni (poetického) jazyka sa strata zmyslu sveta a návrat k nemu v tvorbe Mily Haugovej prejavuje odklonom od jazyka, ktorý stratil svoj pôvodný zmysel, je len zmaterializovaným znakom. Z tohto dôvodu hl'adá spisovatel'ka taký jazyk, v ktorom by súcno bolo rozpoznatel'né (Wyller, 1996: $57-81$ ). ${ }^{17}$

\section{Záver}

Zostáva na čitatel’ovi, či si poéziu z tejto etapy slovenskej poetky osvojí alebo nie. V každom prípade však možno konštatovat' - lyrika Mily Haugovej z jej novej fázy je pokusom preniknút' $\mathrm{k}$ podstate jazyka a takisto zmyslu života. A to je $v$ dnešnej postmodernej dobe a jej virtuálnej realite vytváranej umelými jazykmi a sprevádzanej úplným odcudzením aktuálny jav. Opät' sa teda vrát'me k utópii - aspoň básnik, umelec je schopný vidiet' viac. A tak Mila Haugová pokračuje v odkaze Ingeborg Bachmannovej - v odkaze literatúry ako utópie.

Článok vznikol v rámci riešenia projektu Kega 033UMB-4/2018 - Inovatívne metódy vo výučbe kultúrnych štúdií.

\section{Bibliographic references}

ARISTOTELES. 1996. Poetika. Praha: Svoboda. ISBN 80-205-0295-5.

BACHMANNOVA, I. 1993. Literatura ako utopia. In: Romboid, vol. 28, n. 6, pp. 73 - 80. ISSN 0231-6714.

BACHMANNOVA, I. 1993. Monolog kniezata Myskina $\mathrm{k}$ baletnej pantomíme Idiot Myskin rozprava o poprave. In: Romboid, vol. 28, n. 6, pp. 81-82. ISSN 0231-6714.

BACHMANNOVA, I. 1995. Pravda je ludom pristupna. In: Romboid, vol. 30, n. 7, pp. 6 - 7. ISSN 0231-6714.

\footnotetext{
${ }^{17}$ V dialógu Kratylos sa Platón zamýšl’a nad jazykom tak, že hl’adá reálny jazyk. Objasňuje to prostredníctvom histórie vlastných mien (Kováč), ktoré stratili svoj pôvodný význam. Na rozdiel od dnešného, odetymologizovaného jazyka bolo v tejto dobe súcno v jazyku ešte rozpoznatel'né.
} 
BACHMANNOVA, I. 1995. Telo slova je moj cas. In: Aspekt, vol. 1995, n. 1, pp. 100.

BACHMANNOVA, I. 1995. Chod, myslienka, Ziadne lahodky, Vy slova, Aspekt, vol. 1995, n. 1, pp. 98-99.

BACHMANN, I. 1985. Die kritische Aufnahme der Existentialphilosophie Martin Heideggers. München: Piper. ISBN 349-202-786-5.

BACHMANNOVA, I. 2010a. Ludwig Wittgenstein / K jedne kapitole nejnovejsích dejin filosofie. In: Misto pro nahody. Eseje o literature / hudbe / filosofii. Praha: Triada. pp. 7-16. ISBN 978-80-87256-14-5.

BACHMANNOVA, I. 2010b. Otazky a pseudootazky. I. Frankfurtska prednáska. In: Misto pro nahody. Eseje o literature / hudbe / filosofii. Praha: Triada. pp. 65-79. ISBN 978-8087256-14-5.

BACHMANNOVA, I. 2009. Ctvero vyjadreni. In: Misto pro nahody. Eseje / prozy / rozhovory. Praha: Triada. pp. 231-233. ISBN 978-80-87256-00-8.

BACHMANNOVA, I. 1986. Odroceny cas. Bratislava: Slovensky spisovatel. (Bez ISBN).

BAUDELAIRE, Ch. 1995. Kvety zla. Bratislava: Slovensky spisovatel. ISBN 80-220-06432.

BEDNAROVA, K. 2011. Ku geneze autobiografickeho gesta v literarnom diskurze. In: World Literature Studies, vol. 3, n. 2, pp. 19-27. ISSN 1337-9275.

DOLNIK, J. 2013. Interpretacia ako konstituent cloveka, komunikacie a porozumenia. In: Jazykovedny casopis, vol. 64, n. 2, pp. 93-108. ISSN 1337-6853.

HAUGOVA, M. 1990. Ciste dni. Bratislava: Smena. ISBN 80-221-0060-9.

HAUGOVA, M. 1991. Pralaska. Bratislava: Slovensky spisovatel. ISBN 80-220-0260-7.

HAUGOVA, M. 1993. Nostalgia. Bratislava: Slovensky spisovatel. ISBN 80-220-0447-2.

HAUGOVA, M. 1997. Alfa Centauri. Banska Bystrica: Drewo a srd. ISBN 978-80-9672-7087.

HAUGOVA, M. 2013. Tvrde drevo detstva. Z dennikov a rozhovorov. Levice: KK Bagala. ISBN 978-80-8108-073-9.

HEIDEGGER, M. 2000. O humanismu. Rychnov nad Kneznov: Jezek. ISBN 80-85996-32-4. HUTKOVÁ, A. 2017. The translation theory of the Nitra School and contemporary communication models of literary translation: a case study. In: World Literature Studies, vol. 9, no. 2, pp. 99-114. ISSN 1337-9275.

CHROBAKOVA-REPAR, S. 2002. Mila Haugova. Bratislava: Kalligram. ISBN 80-7149483-6.

JANCOVIC, I. 2013. Nespolahlivost vo fikcnom a faktualnom narative. (Kontexty, diferencie, paralely.) In: World Literature Studies, vol. 5, n. 1, pp. 17-30. ISSN 1337-9275.

KRISTEVA, J. 1978. Die Revolution der poetischen Sprache. Frankfurt am Main: Suhrkamp. ISBN 978-3-518-10949-6.

LACAN, J. 1973. Das Spiegelstadium als Bildner der Ichfunktion. Wie sie uns in der psychoanalytischen Erfahrung erscheint. In: Schriften I. Olten: Walter-Verlag. pp. 61-70. ISBN 3-530-50201-4.

MISTRIK, E. 2016. Esteticka vychova ako nastroj sebareflexie. Bratislava: Pedagogicka fakulta, Univerzita Komenskeho Bratislava. ISBN 978-80-223-4207-0.

PECNIKOVA, J. 2016. Volunteering and activism as forms of active citizenship. In: Teorija in Praksa: druzboslovna revija. Ljubljana, vol. 53, no. 5, pp. 1236-1245. ISSN 0040-3598.

PECNIKOVA, J. - SLATINSKA, A. 2017. The role of Irish language teaching : cultural identity formation or language revitalization? In: European journal of contemporary education, vol. 6, no. 2, pp. 317-327. ISSN 2304-9650.

POCHAT, G. 1986. Kulturgeschichte. Koln: DuMont Verlag. ISBN 3-7701-1893-6.

WITTGENSTEIN, L. 2003. Tractatus logico-philosophicus. Bratislava: Kalligram. ISBN 807-1496-006.

WITTGENSTEIN, L. 2006. O istote. Bratislava: Kalligram. ISBN 80-7149-799-1.

WYLLER, E., A. 1996. Pozdni Platon. Praha: P. Rezek. ISBN 80-86027-00-7. 
ZIMMERMANN, Jorg. 1977. Wittgensteins sprachphilosophische Hermeneutik. Frankfurt am Main: Vittorio Klostermann. ISBN 3-465-01117-1.

Words: 4247

Characters: 30521 (16,96 standard pages)

Mgr. PhD. Eva Höhn

Department of European Cultural Studies

Matej Bel University

Tajovskeho 40, 97401 Banska Bystrica

Slovakia

eva.hohn@umb.sk 